\title{
Slaughter and carcass characteristics of Gokceada, Maltese and Turkish Saanen suckling kids
}

\author{
MUSTAFA ÖZCAN', ALPER YILMAZ¹', BÜLENT EKIZ1', CEMIL TÖLÜ² and TÜRKER SAVAŞ² \\ 'Istanbul University, Veterinary Faculty, Department of Animal Breeding and Husbandry, Avcilar, Istanbul, Turkey, \\ ${ }^{2}$ Canakkale Onsekiz Mart University, Faculty of Agriculture, Department of Animal Science, Canakkale, Turkey
}

\begin{abstract}
Aim of the study was to investigate comparatively the slaughter and carcass characteristics of Gokceada, Maltese and Turkish Saanen suckling kids. Eight suckling male kids at 80-90 days of age from each genotype were used in the study. The kids were collected from dairy goat farms and slaughtered after lairage of an overnight period. Although the kids were at similar age and sex, the slaughter weight and chilled carcass weight of indigenous Gokceada kids were lower than those of Maltese and Turkish Saanen kids $(P<0.001)$. Chilled dressing percentage calculated according to empty body weight was $48.97 \%$ in Gokceada, $51.32 \%$ in Maltese and $52.35 \%$ in Turkish Saanen kids $(\mathrm{P}<0.001)$. There were not statistically significant differences among the breeds in terms of neck, shoulder, ribs and long leg percentages, musculus longissimus dorsi (MLD) section area and back fat thickness $(P>0.05)$. While there were significant differences between breeds in terms of muscle, bone and fat weights in half carcass on the side of Turkish Saanen and Maltese kids, the differences between the genotypes were not significant for percentages of muscle, bone and fat. The carcass structure of suckling kids was small and meat production was low, however, they had very little fat in the carcass. It was concluded that Maltese and Turkish Saanen kids were favourable than Gokceada kids in terms of suckling kid meat production.
\end{abstract}

Keywords: goat, Gokceada, Maltese, Turkish Saanen, kids, carcass

\section{Zusammenfassung}

\section{Schlacht- und Schlachtkörpermerkmale bei Kitzen der Rassen Gökceada, Maltaziege und Türkische Saanenziege}

Ziel der Studie war der Vergleich von Schlacht- und Schlachtkörpermerkmalen bei Kitzen der Rassen Gökceada (G), Maltaziege (M) und Türkische Saanenziege (TS). Je Genotyp wurden acht männliche Kitzen im Alter von 80-90 Tagen aus Milchziegenbetrieben erworben und nach ihrem Transport zur Schlachtstätte am folgenden Tag geschlachtet. Bei den gleichalten Tieren erreichten die einheimischen Gökceade Kitzen gegenüber den beiden anderen Populationen das signifikant geringste Schlachtkörpergewicht. Der Ausschlachtungsgrad betrug in der Reihenfolge G, M, TS 48,97\%, 51,31\% bzw. 52,35\%. Keine Unterschiede zwischen den Rassen zeigten sich beim Anteil von Hals, Schulter, Rippen, Keule der Fläche des M. longissimus dorsi sowie der Rückenfettdicke. Deutliche Unterschiede gab es dagegen bei den Muskel-, Knochen- und Fettgewichten der 
Schlachtkörperhälften wobei M und TS signifikant höhere Werte aufwiesen. Die Anteile dieser drei Gewebe unterschieden sich zwischen den Rassen jedoch nicht. Die Fleischausbeute der untersuchten Milchkitzen war relativ gering jedoch zeigten die Schlachtkörper auch eine geringe Verfettung. Es wurde geschlussfolgert, dass die M und TS besser als die $\mathrm{G}$ für eine Milchlammfleischerzeugung geeignet sind.

Schlüsselwörter: Ziege, Gokceada, Malteserziege, Saanenziege, Kitz, Schlachtkörper

\section{Introduction}

Goat breeding has a great importance in nutrition and economy of indigent people of rural areas in certain countries of World, particularly in developing countries, Mediterranean basin and also in Turkey (GURSOY 2006, BRZOSTOWSKI et al. 2008). Goat products like meat, milk and milk products (e.g. cheese) are generally important animal origin protein sources for indigent people. Turkey is among the leading countries of the world in terms of goat population and goat production potential. The goat population in Turkey is 6.5 million heads, while the total number of goats in the $25 \mathrm{EU}$ countries is 13.9 million (ANONYMOUS 2007). Qualification of the goat meat in the market varies according to the demands of the societies. Meat of the kids slaughtered at very early ages are favoured in the Mediterranean countries like France, Italy, Spain and Portugal and in Latin American countries, while mature goat meat is more accepted in African and South Asian countries (NAUDE and HOFMEYR 1981).

Goat breeding in Turkey is mostly performed by indigent people living in highlands and rural areas, based mainly on the utilisation of natural grasslands and bushes (YALCIN 1986, GURSOY 2006, HEROLD et al. 2007). In Gokceada, which is one of the biggest islands of Turkey, together with organic plant production, animal production studies based on natural habitat are also being carried on. When the farm animal populations on the island are taken into consideration the proportion of sheep and goats is $88.62 \%$ (AKTURK et al. 2005). The breeds bred on the island are Imroz (Gokceada) sheep and Gokceada goat. Although Gokceada goat resembles Hair goat, with its smaller body appearance and certain morphologic characteristics it is an indigenous goat genotype reflecting a different structure. In recent years, an increasing demand to dairy type goat breeds by the breeders who have better breeding and feeding conditions has been observed especially in the European part (Thrace) of Turkey. In the dairy goat breeding managements mostly Turkish Saanen and Maltese goat breeds are preferred. In these managements, so as to obtain more marketable milk from the goats, kids are sold and slaughtered at early ages (PALA et al. 2005).

The aim of the study was to determine the meat production potentialities of dairy type Turkish Saanen and Maltese suckling kids in comparison with Gokceada goats, which is an indigenous breed of Turkey, under semi-intensive conditions and thereby to produce scientific knowledge concerning the breed choice for the breeders who supply better breeding and feeding conditions to goats instead of traditional production system based on utilisation of natural grasslands and bushes. 


\section{Material and methods}

The research protocol of the current study was approved by the Ethic Committee of Istanbul University Veterinary Faculty (Approval number: 2007/193).

\section{Animals and slaughter procedure}

A total of 24 suckling kids from Turkish Saanen, Gokceada and Maltese breeds were used in the study. Each genotype group consisted of 8 singleton and male kids. Kids were purchased from a commercial farm in Çanakkale province. Kids were kept together with their dams and suckled during whole day until weaning. Grower concentrate and alfalfa hay were also used in the feeding of Turkish Saanen, Maltese and Gokceada kids in addition to their mothers milk. Immediately after weaning at 80-90 days of age, kids were transported to the experimental slaughterhouse of Istanbul University Veterinary Faculty. Kids were slaughtered at following morning after lairage of an overnight period.

On the day of slaughter, pre-slaughter live weights were recorded and then kids were slaughtered. After slaughter, non-carcass components such as head, skin, feet, lungs and trachea, liver, heart, spleen, pancreas, gastro-intestinal tract and testicles were removed, and then hot carcass was obtained. The weights of non-carcass components and hot carcass were recorded and the carcasses were numbered. Gastro-intestinal tract content was removed, and the weight of empty stomachs and empty intestines were recorded. Empty body weight (EBW) was estimated by subtracting the weight of gastro-intestinal tract content from the preslaughter live weight. The percentages of internal organs were calculated according to empty body weight.

\section{Carcass analysis}

The carcasses were chilled at $4{ }^{\circ} \mathrm{C}$ for $24 \mathrm{~h}$. Cold dressing percentage was calculated using preslaughter weight $\left(\mathrm{DP}_{1}\right)$ and also using empty body weight $\left(\mathrm{DP}_{2}\right)$. Before the carcass jointing, kidney, kidney knob and channel fat (KKCF) and tail were removed from carcasses and weighed. Chilled carcasses were then split along the vertebral column into left and right halves. The right side of each carcass was separated into neck, shoulder, flank, ribs and long leg joints according to the methodology described by COLOMERROCHER et al. (1987), and weights of half carcass joints were recorded. Musculus longissimus dorsi (MLD) section area and back fat thickness were measured between 13th thoracic and first lumbar vertebrae according to description of BOGGS and MERKEL (1993).

The right side of each carcass was used to determine tissue composition of carcass joints and these joints were frozen and stored at $-18^{\circ} \mathrm{C}$. One day prior to tissue dissection, frozen joints were taken from the freezer and thawed at $4^{\circ} \mathrm{C}$ for $24 \mathrm{~h}$. The procedures reported by FISHER and de BOER (1994) were used to determine the muscle, fat and bone percentage of each joint.

\section{Statistical analyses}

In order to determine the effect of genotype on slaughter and carcass quality characteristics, one-way ANOVA was performed using SPSS 10.0 statistical package (SPSS 1999). If the effect of genotype was found significant, Duncan's multiple range tests were used to evaluate the significance of difference. 


\section{Results and discussion}

\section{Organs and fat content}

Slaughter and organ weights of Gokceada, Maltese and Turkish Saanen suckling kids are presented in Table 1 and proportions of these parts to empty body weight are presented in Table 2.

Table 1

Means and standard errors of non-carcass components weights in Gokceada, Maltese and Turkish Saanen suckling kids

Mittelwerte und Standardfehler der Teilstückgewichte des Schlachtkörpers bei Gokceada, Malteserziege und Türkischen Saanen Kitzen

\begin{tabular}{lcrrrrrr}
\hline \multirow{2}{*}{ Characteristics } & \multicolumn{3}{c}{ Gokceada } & \multicolumn{3}{c}{ Maltese } & \multicolumn{3}{c}{ Turkish Saanen } \\
& Mean & \multicolumn{1}{c}{ SE } & Mean & \multicolumn{1}{c}{ SE } & Mean & \multicolumn{1}{c}{ SE } & \\
\hline Slaughter weight, kg & $10.73^{\mathrm{b}}$ & 0.48 & $16.44^{\mathrm{a}}$ & 0.66 & $15.57^{\mathrm{a}}$ & 0.71 & $24.04^{* * *}$ \\
Head weight, kg & $0.79^{\mathrm{b}}$ & 0.03 & $1.10^{\mathrm{a}}$ & 0.04 & $1.02^{\mathrm{a}}$ & 0.03 & $23.25^{* * *}$ \\
Skin weight, kg & $0.82^{\mathrm{c}}$ & 0.07 & $1.27^{\mathrm{a}}$ & 0.04 & $0.10^{\mathrm{b}}$ & 0.05 & $18.61^{* * *}$ \\
Feet weight, kg & $0.34^{\mathrm{b}}$ & 0.02 & $0.49^{\mathrm{a}}$ & 0.07 & $0.52^{\mathrm{a}}$ & 0.02 & $5.81^{* * *}$ \\
Lungs and trachea weight, kg & $0.23^{\mathrm{b}}$ & 0.01 & $0.34^{\mathrm{a}}$ & 0.02 & $0.30^{\mathrm{a}}$ & 0.02 & $7.85^{* *}$ \\
Liver weight, kg & $0.24^{\mathrm{b}}$ & 0.01 & $0.39^{\mathrm{a}}$ & 0.02 & $0.35^{\mathrm{a}}$ & 0.03 & $18.83^{* * *}$ \\
Heart weight, kg & $0.05^{\mathrm{b}}$ & $<0.01$ & $0.08^{\mathrm{a}}$ & $<0.01$ & $0.08^{\mathrm{a}}$ & 0.01 & $17.48^{* * *}$ \\
Spleen weight, kg & $0.03^{\mathrm{b}}$ & $<0.01$ & $0.04^{\mathrm{a}}$ & $<0.01$ & $0.03^{\mathrm{a}}$ & $<0.01$ & $4.63^{*}$ \\
Omental fat weight, kg & $0.06^{\mathrm{b}}$ & 0.01 & $0.13^{\mathrm{a}}$ & $<0.01$ & $0.08^{\mathrm{ab}}$ & 0.01 & $4.18^{*}$ \\
Kidney weight, kg & $0.03^{\mathrm{b}}$ & $<0.01$ & $0.05^{\mathrm{a}}$ & $<0.01$ & $0.04^{\mathrm{b}}$ & $<0.01$ & $16.93^{* * *}$ \\
Kidney knob and channel fat weight, $\mathrm{kg}$ & 0.02 & $<0.01$ & 0.05 & 0.01 & 0.04 & 0.01 & $2.72^{\text {ns }}$ \\
Full stomach weight, kg & $1.49^{\mathrm{b}}$ & 0.09 & $2.19^{\mathrm{a}}$ & 0.14 & $2.29^{\mathrm{a}}$ & 0.13 & $13.03^{* * *}$ \\
Empty stomach weight, kg & $0.43^{\mathrm{c}}$ & 0.02 & $0.62^{\mathrm{a}}$ & 0.03 & $0.53^{\mathrm{b}}$ & 0.02 & $16.18^{* * *}$ \\
Full intestine weight, kg & $1.09^{\mathrm{b}}$ & 0.05 & $1.41^{\mathrm{ab}}$ & 0.09 & $1.60^{\mathrm{a}}$ & 0.17 & $4.90^{*}$ \\
Empty intestine weight, kg & $0.82^{\mathrm{b}}$ & 0.03 & $1.02^{\mathrm{a}}$ & 0.07 & $1.10^{\mathrm{a}}$ & 0.07 & $6.85^{* *}$ \\
Gastro-intestinal tract content weight, kg & $1.34^{\mathrm{b}}$ & 0.13 & $1.95^{\mathrm{a}}$ & 0.13 & $2.26^{\mathrm{a}}$ & 0.21 & $8.79^{* *}$ \\
Testicle weight, kg & $0.02^{\mathrm{c}}$ & $<0.01$ & $0.05^{\mathrm{a}}$ & $<0.01$ & $0.04^{\mathrm{b}}$ & $<0.01$ & $28.06^{* * *}$ \\
\hline
\end{tabular}

ns not significant $(P>0.05), \quad a, b, c$ Differences between the means carrying various letters in the same line are significant $\left({ }^{*} P<0.05,{ }^{* *} P<0.01,{ }^{* * *} P<0.001\right)$.

Although all the kids in Gokceada, Turkish Saanen and Maltese breeds were the same sex, at similar ages and were slaughtered at weaning, the differences between slaughter weights were significant $(P<0.001)$. The mean slaughter weight of Gokceada kids was $4.84 \mathrm{~kg}$ lower than that of Turkish Saanen and $5.71 \mathrm{~kg}$ lower than that of Maltese kids. These differences in slaughter weight affected the organ weights and the differences between genotypes in terms of organ weights were also statistically significant on the side of Turkish Saanen and Maltese kids. The slaughter weight differences between the breeds might be explained by the improvement status of breeds. Turkish Saanen and Maltese goat breeds are improved breeds in terms of dairy characteristics while Gokceada is a dual purpose indigenous goat breed which has survived by natural selection on the island for hundreds of years. Similar to the results of the present study, SANTOS et al. (2007) in Serrana, Bravia and Serrana $\times$ Bravia goats and KADIM et al. (2003) in Batina, Dhofori and Jabal Akdhar goats reported different slaughter weights as the result of different genotypes. 
Table 2

Means and standard errors of non-carcass components percentages in Gokceada, Maltese and Turkish Saanen suckling kids

Mittelwerte und Standardfehler der Teilstückanteile des Schlachtkörpers bei Gokceada, Malteserziege und Türkischen Saanen Kitzen

\begin{tabular}{lccccccc}
\hline \multirow{2}{*}{ Characteristics } & \multicolumn{3}{c}{ Gokceada } & \multicolumn{3}{c}{ Maltese } & \multicolumn{3}{c}{ Turkish Saanen } & \multirow{2}{*}{$\mathrm{F}$} \\
& Mean & SE & Mean & SE & Mean & SE & \\
\hline Head, \% & $7.40^{\mathrm{a}}$ & 0.13 & $6.69^{\mathrm{b}}$ & 0.14 & $6.56^{\mathrm{b}}$ & 0.18 & $9.08^{* *}$ \\
Skin, \% & $7.55^{\mathrm{a}}$ & 0.32 & $7.75^{\mathrm{a}}$ & 0.18 & $6.36^{\mathrm{b}}$ & 0.19 & $9.70^{* *}$ \\
Feet, \% & 3.11 & 0.05 & 3.07 & 0.40 & 3.32 & 0.06 & $0.32^{\text {ns }}$ \\
Lungs and trachea, \% & 2.16 & 0.08 & 2.04 & 0.12 & 1.90 & 0.08 & $1.81^{\text {ns }}$ \\
Liver, \% & 2.28 & 0.06 & 2.38 & 0.08 & 2.22 & 0.03 & $1.81^{\text {ns }}$ \\
Heart, \% & 0.49 & 0.01 & 0.50 & 0.01 & 0.50 & 0.02 & $0.22^{\text {ns }}$ \\
Spleen, \% & 0.25 & 0.02 & 0.22 & 0.01 & 0.22 & 0.01 & $1.33^{\text {ns }}$ \\
Omental fat, \% & 0.52 & 0.09 & 0.75 & 0.12 & 0.50 & 0.07 & $2.11^{\text {ns }}$ \\
Kidney, \% & $1.44^{\mathrm{a}}$ & 0.04 & $1.31^{\mathrm{b}}$ & 0.04 & $1.08^{\mathrm{c}}$ & 0.04 & $19.93^{* * *}$ \\
Kidney knob and channel fat, \% & 1.04 & 0.14 & 1.25 & 0.19 & 1.07 & 0.20 & $0.45^{\text {ns }}$ \\
Empty stomach, \% & $4.01^{\mathrm{a}}$ & 0.14 & $3.74^{\mathrm{a}}$ & 0.03 & $3.42^{\mathrm{b}}$ & 0.10 & $8.52^{* *}$ \\
Empty intestine, \% & $7.67^{\mathrm{a}}$ & 0.19 & $6.20^{\mathrm{c}}$ & 0.21 & $7.04^{\mathrm{b}}$ & 0.13 & $16.83^{* * *}$ \\
Testicle, \% & $0.19^{\mathrm{c}}$ & 0.02 & $0.28^{\mathrm{a}}$ & 0.01 & $0.24^{\mathrm{b}}$ & 0.01 & $10.70^{* * *}$ \\
\hline
\end{tabular}

ns not significant $(P>0.05)$, a,b,c Differences between the means carrying various letters in the same line are significant $\left({ }^{* *} P<0.01,{ }^{* * *} P<0.001\right)$.

Other than head, skin, kidney, empty stomachs, empty intestines and testicle percentages, the differences between breeds in terms of organ percentages were not significant. Head, kidney, empty stomach and empty intestine percentages of Gokceada and skin and testicle percentages of Maltese kids were higher than the other genotypes. It was reported that the percentages of head and kidney decreased with the increase in slaughter weight (MARICHAL et al. 2003, PENA et al. 2007, PIENIAK-LENDZION et al. 2009). Head and kidney percentages of Gokceada kids were higher than those of Turkish Saanen and Maltese kids and this could be explained by the lower slaughter weight of Gokceada kids.

The mean skin percentages of Gokceada and Maltese kids were 1.19\% and 1.38\% higher than those of Turkish Saanen kids. The differences might be related to the denser and longer hair production of Gokceada and Maltese kids than Turkish Saanen kids. The skin percentages of different breeds slaughtered at $10-15 \mathrm{~kg}$ live weight were reported to be $9.78-10.34 \%$ (MARICHAL et al. 2003, PENA et al. 2007, SANTOS et al. 2007). The skin percentage results of the three breeds in the present study were lower than the results reported and the differences between studies might be explained by the differences in genotype.

Testicle percentages of Maltese and Turkish Saanen kids were higher than that of Gokceada kids. This might be the result of Gokceada breed's being an indigenous breed reaching sexual maturity later than the improved breeds. Similar results were reported in different studies concerning indigenous and improved goat breeds (KADIM et al. 2003, KOŞUM et al. 2003).

Omental and kidney knob and channel fat (KKCF) percentages in different breeds (DHANDA et al. 1999a, 2003, PENA et al. 2007, SANTOS et al. 2007) were higher than omental $(0.50-0.75 \%)$ and KKCF (1.04-1.25\%) percentages determined in the present study. These results indicate the lower fat deposition characteristic of Gokceada, Maltese and Turkish Saanen kids and might be evaluated as favourable with regard to the market demand. 


\section{Dressing percentage}

The differences in slaughter weight among the breeds also affected chilled carcass weights. Gokceada kids yielded $4.61 \mathrm{~kg}$ chilled carcass weight, while Turkish Saanen and Maltese kids yielded $6.97 \mathrm{~kg}$ and $7.44 \mathrm{~kg}$, respectively (Table 3). Chilled carcass weights were $4.6-6 \mathrm{~kg}$ in kids of different goat breeds slaughtered at $10 \mathrm{~kg}$ and were $6.3-8.2 \mathrm{~kg}$ in kids of different breeds slaughtered at 15-16 kg (DHANDA et al. 1999a, RINGDORFER 2001, DHANDA et al. 2003, MARICHAL et al. 2003, HEROLD et al. 2007, PENA et al. 2007, SANTOS et al. 2007). The carcass weights of Turkish Saanen and Maltese kids were in accordance with these results of different studies. The carcass weight of Gokceada kids was close to the lowest carcass weight reported.

Table 3

Means and standard errors of cold carcass characteristics, weights and percentages of carcass joints in Gokceada, Maltese and Turkish Saanen suckling kids.

Mittelwerte und Standardfehler der kalten Teilstückgewichte und -anteile bei Gokceada, Malteserziegen und Türkischen Saanen Kitzen

\begin{tabular}{|c|c|c|c|c|c|c|c|}
\hline \multirow{2}{*}{ Characteristics } & \multicolumn{2}{|c|}{ Gokceada } & \multicolumn{2}{|c|}{ Maltese } & \multicolumn{2}{|c|}{ Turkish Saanen } & \multirow{2}{*}{$F$} \\
\hline & Mean & SE & Mean & SE & Mean & SE & \\
\hline Chilled carcass weight, $\mathrm{kg}$ & $4.61^{b}$ & 0.26 & $7.44^{\mathrm{a}}$ & 0.37 & $6.97^{\mathrm{a}}$ & 0.30 & $23.63^{* * *}$ \\
\hline Dressing percentage $-1^{\mathrm{DP} 1}, \%$ & 42.82 & 0.80 & 45.17 & 0.67 & 44.81 & 0.62 & $3.21^{\mathrm{ns}}$ \\
\hline Dressing percentage- $2^{\mathrm{DP} 2}, \%$ & $48.97^{b}$ & 0.54 & $51.32^{\mathrm{a}}$ & 0.35 & $52.35^{\mathrm{a}}$ & 0.39 & $16.09 * * *$ \\
\hline Chilling loss, $\%$ & $3.83^{\mathrm{a}}$ & 0.10 & $3.19^{c}$ & 0.09 & $3.51^{\mathrm{b}}$ & 0.10 & $11.11^{* *}$ \\
\hline Neck weight, kg & $0.21^{\mathrm{b}}$ & 0.01 & $0.34^{\mathrm{a}}$ & 0.02 & $0.34^{\mathrm{a}}$ & 0.02 & $21.64^{* * *}$ \\
\hline Shoulder weight, kg & $0.48^{\mathrm{b}}$ & 0.03 & $0.76^{a}$ & 0.04 & $0.74^{\mathrm{a}}$ & 0.04 & $20.25^{* * *}$ \\
\hline Flank weight, kg & $0.25^{\mathrm{b}}$ & 0.02 & $0.40^{\mathrm{a}}$ & 0.02 & $0.37^{\mathrm{a}}$ & 0.03 & $9.71^{* *}$ \\
\hline Ribs weight, kg & $0.53^{b}$ & 0.03 & $0.86^{\mathrm{a}}$ & 0.05 & $0.79^{\mathrm{a}}$ & 0.03 & $22.42^{* * *}$ \\
\hline Sirloin weight, kg & $0.35^{\mathrm{b}}$ & 0.02 & $0.54^{\mathrm{a}}$ & 0.03 & $0.52^{\mathrm{a}}$ & 0.02 & $21.98^{* * *}$ \\
\hline Loin weight, kg & $0.18^{c}$ & 0.02 & $0.32^{\mathrm{a}}$ & 0.02 & $0.27^{\mathrm{b}}$ & 0.01 & $17.39 * * *$ \\
\hline Long leg weight, kg & $0.75^{\mathrm{b}}$ & 0.05 & $1.20^{\mathrm{a}}$ & 0.06 & $1.14^{\mathrm{a}}$ & 0.05 & $21.28^{* * *}$ \\
\hline Tail weight, kg & $0.01^{\mathrm{b}}$ & $<0.01$ & $0.02^{\mathrm{a}}$ & $<0.01$ & $0.01^{\mathrm{a}}$ & $<0.01$ & $9.66^{* *}$ \\
\hline Neck percentage, $\%$ & 9.08 & 0.31 & 9.31 & 0.34 & 9.76 & 0.62 & $0.62^{\mathrm{ns}}$ \\
\hline Shoulder percentage,\% & 20.76 & 0.34 & 20.51 & 0.22 & 21.39 & 0.43 & $1.79^{\text {ns }}$ \\
\hline Flank percentage, $\%$ & 11.02 & 0.63 & 10.92 & 0.28 & 10.54 & 0.35 & $0.33^{\text {ns }}$ \\
\hline Ribs percentage, $\%$ & 23.13 & 0.45 & 23.41 & 0.52 & 22.90 & 0.53 & $0.25^{\mathrm{ns}}$ \\
\hline Sirloin percentage, $\%$ & 15.23 & 0.45 & 14.68 & 0.28 & 15.08 & 0.40 & $0.55^{\mathrm{ns}}$ \\
\hline Loin percentage, $\%$ & 7.90 & 0.42 & 8.73 & 0.36 & 7.81 & 0.22 & $2.20^{\mathrm{ns}}$ \\
\hline Long leg percentage, $\%$ & 32.96 & 0.26 & 32.65 & 0.30 & 32.75 & 0.45 & $0.21^{\mathrm{ns}}$ \\
\hline MLD section area, $\mathrm{cm}^{2}$ & 7.08 & 0.33 & 8.22 & 0.29 & 7.92 & 0.41 & $2.94^{\mathrm{ns}}$ \\
\hline Back fat thickness, mm & 0.13 & 0.02 & 0.21 & 0.02 & 0.21 & 0.04 & $2.81^{\text {ns }}$ \\
\hline
\end{tabular}

ns not significant $(P>0.05), \quad a, b, c$ Differences between the means carrying various letters in the same line are significant $\left({ }^{* *} P<0.01,{ }^{* * *} P<0.001\right)$. DP1 dressing percentage based on slaughter weight, DP2 dressing percentage based on empty body weight

The mean chilled dressing percentages according to slaughter weight were $42.82-45.17 \%$ in the present study (Table 3) and the differences between the breeds were not statistically significant $(P>0.05)$. However, breed had a significant effect on dressing percentages according to empty body weight $(P<0.001)$. Dressing percentages in Maltese and Turkish Saanen kids were higher than those of Gokceada kids. These differences might be related to faster muscle, bone and fat production of Maltese and Turkish Saanen 
than Gokceada kids. It was reported in different studies that chilled dressing percentages in goats varied depending upon breed, slaughter weight, sex and nutrition and that dressing percentages were lower in kids slaughtered at $10 \mathrm{~kg}$ and were higher in kids slaughtered at 15+ kg (MANFREDINI et al. 1988, KOYUNCU et al. 1996, DHANDA et al. 1999a, 2003, MARICHAL et al. 2003, PENA et al. 2007, SANTOS et al. 2007). The dressing percentages according to empty body weight results in the present study were generally in accordance with the results reported in the studies mentioned above.

The mean chilling loss in the present study was $3.19-3.83 \%$ (Table 3). The highest chilling loss was in Gokceada and the lowest was in Maltese kids. It was reported that chilling loss decreased with the increase in slaughter weight (MARICHAL et al. 2003, PENA et al. 2007). The lower chilling loss in Gokceada kid carcasses might be the result of their lower slaughter weight.

\section{Carcass composition}

The weights and percentages of carcass parts of Gokceada, Maltese and Turkish Saanen kids are presented in Table 3. There were significant differences among the breeds in terms of neck, shoulder, flank, ribs, long leg and tail weights $(P<0.001)$. Almost the weights of all the carcass parts in Turkish Saanen and Maltese kids were similar and were higher than those of Gokceada kids. The differences among the breeds in terms of carcass parts percentages were not significant $(P>0.05)$. In all the breeds, the chilled carcass was composed of about $32 \%$ long leg, $23 \%$ ribs; $21 \%$ shoulder, $11 \%$ flank and $9 \%$ neck. The remaining $4 \%$ was kidney, KKCF and tail which are accepted to remain in the suckling kid carcasses. When the carcass parts percentages results of the present study are compared to those of other studies, it can be observed that there are differences varying between \pm 2 and $\pm 6 \%$. These might be the result of the differences in breed, slaughter age, slaughter weight and jointing technique (RINGDORFER 2001, KOŞUM et al. 2003, MARICHAL et al. 2003, DASKIRAN et al. 2006, HEROLD et al. 2007, KOYUNCU et al. 2007, PENA et al. 2007, SANTOS et al. 2007).

The differences among the breeds in terms of MLD section area and back fat thickness were not significant $(P>0.05)$. The mean MLD section area was $7.08-8.22 \mathrm{~cm}^{2}$ and mean back fat thickness was $0.13-0.21 \mathrm{~mm}$ in the breeds in the present study. MLD section areas were reported to be $6.5-9 \mathrm{~cm}^{2}$ in Capretto, $11.8-13.3 \mathrm{~cm}^{2}$ in Chevon and 7.1-14.6 $\mathrm{cm}^{2}$ in heavier carcasses (DHANDA et al. 1999a, 2003, KOŞUM et al. 2003, DASKIRAN et al. 2006, KOYUNCU et al. 2007). The MLD section area result of Gokceada kids were in accordance with those of Capretto carcasses. However, Maltese and Turkish Saanen kids had MLD section areas lower than those of Chevon carcasses. Back fat thicknesses of the breeds in the present study were very low.

There were significant differences among the breeds in terms of muscle, bone, subcutaneous fat, intermuscular fat and other tissues weights (Table 4). The highest muscle content in half carcass was in Maltese $(2060 \mathrm{~g})$ and Turkish Saanen $(1949 \mathrm{~g})$ kids. Gokceada kids produced approximately $700 \mathrm{~g}$ less muscle than did the other two breeds. When the carcass components were evaluated according to their percentages in the carcass, the differences among Turkish Saanen, Gokceada and Maltese kids were not significant. In the half carcass of the breeds, the percentages were $57.9-59.7 \%$ for muscle, 
23.1-23.7\% for bone, $2.1-2.4 \%$ for subcutaneous fat, $7.5-8.7 \%$ for intermuscular fat and $3.1-3.6 \%$ for other tissues. When the carcass component percentages of the present study are compared to the results of studies on different breeds with similar characteristics, other than bone percentage, all the results of the present study are at lower levels (DHANDA et al. 1999b, MARICHAL et al. 2003, KOYUNCU et al. 2007, PENA et al. 2007, SANTOS et al. 2007). The differences between studies might be the result of the differences in genotypes and feeding.

Table 4

Means and standard errors of dissected half carcass composition in Gokceada, Maltese and Turkish Saanen suckling kids

Mittelwerte und Standardfehler der Gewebegewichte und -anteile bei Gokceada, Malteserziege und Türkischen Saanen Kitzen

\begin{tabular}{|c|c|c|c|c|c|c|c|}
\hline \multirow{2}{*}{ Characteristics } & \multicolumn{2}{|c|}{ Gokceada } & \multicolumn{2}{|c|}{ Maltese } & \multicolumn{2}{|c|}{ Turkish Saanen } & \multirow{2}{*}{$\mathrm{F}$} \\
\hline & Mean & SE & Mean & SE & Mean & SE & \\
\hline Muscle weight, g & $1338.71^{b}$ & 93.36 & $2060.09^{a}$ & 92.53 & $1949.11^{a}$ & 80.82 & $17.56^{* * *}$ \\
\hline Bone weight, $\mathrm{g}$ & $529.54^{b}$ & 36.17 & $825.23^{\mathrm{a}}$ & 46.25 & $789.74^{\mathrm{a}}$ & 40.65 & $13.52^{* * *}$ \\
\hline Subcutaneous fat weight, g & $57.15^{\mathrm{b}}$ & 14.07 & $127.75^{\mathrm{a}}$ & 20.44 & $73.96^{\mathrm{ab}}$ & 18.73 & $3.83^{*}$ \\
\hline Intermuscular fat weight, g & $173.25^{b}$ & 26.04 & $317.82^{\mathrm{a}}$ & 47.43 & $291.37^{\mathrm{a}}$ & 26.39 & $4.42^{*}$ \\
\hline Total fat weight, $g$ & $230.40^{\mathrm{b}}$ & 38.65 & $445.56^{\mathrm{a}}$ & 64.96 & $365.32^{\mathrm{ab}}$ & 39.84 & $4.38^{*}$ \\
\hline Other tissues ${ }^{1}$ weight, $g$ & $70.10^{\mathrm{b}}$ & 6.13 & $123.31^{\mathrm{a}}$ & 7.02 & $120.18^{a}$ & 10.71 & $10.68^{* * *}$ \\
\hline Evaporation loss, $\mathrm{g}$ & $80.60^{b}$ & 7.56 & $115.88^{\mathrm{a}}$ & 6.01 & $133.32^{\mathrm{a}}$ & 9.34 & $10.70^{* * *}$ \\
\hline Muscle percentage, $\%$ & 59.69 & 0.73 & 57.88 & 0.95 & 58.11 & 0.74 & $1.33^{\mathrm{ns}}$ \\
\hline Bone percentage, $\%$ & 23.66 & 0.66 & 23.13 & 0.49 & 23.55 & 0.79 & $0.17^{\mathrm{ns}}$ \\
\hline Subcutaneous fat percentage, $\%$ & 2.44 & 0.44 & 3.47 & 0.41 & 2.08 & 0.45 & $2.83^{\mathrm{ns}}$ \\
\hline Intermuscular fat percentage, $\%$ & 7.52 & 0.59 & 8.72 & 0.90 & 8.67 & 0.69 & $0.75^{\mathrm{ns}}$ \\
\hline Total fat percentage, $\%$ & 9.95 & 0.95 & 12.19 & 1.18 & 10.75 & 0.85 & $1.21^{\mathrm{ns}}$ \\
\hline Other tissues ${ }^{1}$ percentage, $\%$ & 3.11 & 0.10 & 3.50 & 0.22 & 3.61 & 0.34 & $0.91^{\mathrm{ns}}$ \\
\hline Evaporation loss, $\%$ & 3.58 & 0.17 & 3.31 & 0.27 & 3.98 & 0.23 & $2.27^{\mathrm{ns}}$ \\
\hline Muscle / bone & 2.53 & 0.08 & 2.51 & 0.06 & 2.48 & 0.08 & $0.10^{\mathrm{ns}}$ \\
\hline Muscle / total fat & 6.31 & 0.66 & 5.08 & 0.59 & 5.66 & 0.47 & $1.09^{\text {ns }}$ \\
\hline Subcutaneous fat/Intermuscular fat & 0.32 & 0.04 & 0.41 & 0.04 & 0.25 & 0.05 & $3.30^{\mathrm{ns}}$ \\
\hline
\end{tabular}

ns not significant $(P>0.05), \quad a, b$ Differences between the means carrying various letters in the same line are significant $\left({ }^{*} P<0.05,{ }^{* * *} P<0.001\right),{ }^{1}$ major blood vessels, tendons, larger nerves and lymph nodes

When all the carcass characteristics in the present study are evaluated together, it can be concluded that in the suckling kid genotypes slaughtered at 10-15 kg live weight, the amount of consumable meat products produced were low. General carcass structures were small with a very little fat content. Although Maltese kids had numerically higher slaughter and carcass results than did Turkish Saanen kids, the differences between these breeds were not statistically significant. As a result, it was found that Maltese and Turkish Saanen kids were superior to Gokceada kids in terms of suckling kid meat production which is common in the Mediterranean countries.

\section{Acknowledgements}

The authors would like to thank Dr. Omur Kocak and Hulya Yalcintan for their assistance in carcass dissection. The present study was supported by The Scientific and Technological 
Research Council of Turkey (TUBITAK) (Project No: 1070 280) and Research Fund of Istanbul University (Project No: UDP-2051/31012008).

\section{References}

Akturk D, Savran F, Hakyemez H, Daş G, Savaş T (2005) Socio-economic analysis of animal breeding enterprises under extensive conditions in Gökçeada. Tarım Bilimleri Dergisi 11, 229-35 [in Turkish]

Anonymous (2007) Food and Agriculture Organization of The United Nations. http://faostat.fao.org/site/573/desktopdefault.aspx?pageıd=573\#ancor [last accessed 11.12.2009]

Boggs DL, Merkel RA (1993) Live animal carcass evaluation and selection manual. 4th ed., Kendall/Hunt Publishing Company, lowa, USA, 161-82

Brzostowski H, Niznikowski R, Tanski Z (2008) Quality of goat meat from purebred French Alpine kids and Boer crossbreeds. Arch Tierz 51, 381-8

Colomer-Rocher F, Morand-Fehr P, Kirton AH (1987) Standard methods and procedures for goat carcass evaluation, jointing and tissue separation. Livest Prod Sci 17, 149-59

Daskiran I, Kor A, Bingöl M (2006) Slaughter and carcass characteristics of Norduz male kids raised in either intensive and pasture conditions. Pakistan J Nutr 5, 274-7

Dhanda JS, Taylor DG, Mccosker JE, Murray PJ (1999a) The influence of goat genotype on the production of capretto and chevon carcass. 1. Growth and carcass characteristics. Meat Sci 52, 355-61

Dhanda JS, Taylor DG, Mccosker JE, Murray PJ (1999b) The influence of goat genotype on the production of capretto and chevon carcass. 3. Dissected carcass composition. Meat Sci 52, 369-74

Dhanda JS, Taylor DG, Murray PJ (2003) Part 1. Growth, carcass and meat quality parameters of male goats: Effects of genotype and liveweight at slaughter. Small Rumin Res 50, 57-66

Fisher AV, De Boer H (1994) The EAAP standard method of sheep carcass assessment and dissection procedures. Livest Prod Sci 38, 149-59

Gursoy (2006) Economics and profitability of sheep and goat production in Turkey under new support regimes and market conditions. Small Rumin Res 62, 181-91

Herold P, Snell H, Tawfik ES (2007) Growth, carcass and meat quality parameters of purebred and crossbred goat kids in extensive pasture. Arch Tierz 50, 186-96

Kadim IT, Mahgoub DS, Al-Ajmi DS, Al-Maqbaly RS, Al-Saqri NM, Ritchie A (2003) An evaluation of the growth, carcass and meat quality characteristics of Omani goat breeds. Meat Sci 66, 203-10

Koşum N, Alçiçek A, Taşkın T, Önenç A (2003) Fattening performance and carcass characteristics of Saanen and Bornova male kids under an intensive management system. Czech J of Anim Sci 48, 379-86

Koyuncu M, Duru S, Kara Ş, Öziş Ş, Tuncel E (2007) Effect of castration on growth and carcass traits in Hair Goat kids under a semi-intensive system in the South Marmara Region of Turkey. Small Rumin Res 72, 38-44

Koyuncu M, Tuncel E, Akman N (1996) Fattening performance and carcass characteristics of Angora Goat male kids in intensive and pasture condition. Turkish J Vet Anim Sci 20, 157-61

Manfredini M, Massari M, Cavani C, Falaschini AF (1988) Carcass characteristics of male alpine kids slaughtered at different weights. Small Rumin Res 1, 49-58

Marichal A, Castro N, Capote J, Zamorano MJ, Argüello A (2003) Effects of Live weight at slaughter (6, 10, and $25 \mathrm{~kg}$ ) on kid carcass and meat quality. Livest Prod Sci 83, 247-56

Naude RT, Hofmeyr HS (1981) Meat production. In: Gall C. (ed.): Goat production. pp. 285-307, Academic Press, London

Pala A, Savas T, Ugur F, Das G (2005) Growth curves of Turkish Saanen goats kids grouped for weight and body mass index. Arch Tierz 48, 185-93

Pena F, Perea J, Garcia A, Acero R (2007) Effects of weight at slaughter and sex on the carcass characteristics of Florida suckling kids. Meat Sci 75, 543-50

Pieniak-Lendzion K, Niedziolka R, Borkowska T (2009) Some carcass traits and physicochemical composition of White Improved breed goat kids slaughtered at 90 and 180 days of age. Arch Tierz $52,425-31$

Ringdorfer $F$ (2001) The effect of genotype, sex and final weight on slaughter performance of kids. Arch Tierz 44 Special Issue, 385-90

Santos VAC, Silva AO, Cardoso JVF, Silvestre AJD, Silva SR, Martins C, Azevedo JMT (2007) Genotype and sex effects on carcass and meat quality of suckling kids protected by the PGI »Cabrito De Barroso«. Meat Sci 75, 725-36 
SPSS (1999) Statistical Package for the Social Sciences, Release 10.0. SPSS Inc. IL, Chicago, USA

Yalcin (1986) Sheep and goats in Turkey. FAO Animal Production and Health Paper No: 60, Rome, Italy

Received 2 June 2009, accepted 11 December 2009.

Corresponding author:

MUSTAFA ÖZCAN

email: muscan@istanbul.edu.tr

Department of Animal Breeding and Husbandry, Veterinary Faculty, Istanbul University, 34320, Avcilar, Istanbul, Turkey 